\title{
Some Remarkable Instances of Improvement of Flower Characters in Cultivated Cherries
}

\author{
$\mathrm{By}$
}

\section{Miyoshi}

In my experimental garden stands a young tree of Prunus serrulata LINDL. $f$. communis Miyos. (n o m. ja p. Koshioyama), raised from the seed of 1910, produced by self-fertilization.

The tree differs from any other tree of the same kind of cherry, raised from the seeds of $1907,{ }^{\prime}$ in having the flowers much larger, more pinkish and decidedly fragrant. In consequence of the new properties the cherry tree (Prunus serrulata Lind. $f$. Koshioyamaodora nov. $f$. $\mathrm{n} \mathrm{o} \mathrm{m.} \mathrm{j}$ a p. Koshioyama-nioi) is very beautiful and can easily be distinguished from other trees of the same kind. In the mother tree, the flowers are smaller, faintly pinkish and not fragrant.

Why in this single offspring, unlike others, the improvement of flower characters took place is unknown. It seems, however, to be a remarkable instance of progressive mutation, which, as I have myself observed, occurs frequently in several forms of Prunus mutabilis Mryos., more especially in the forms of Prunus serrulata LINDL.

In this respect a seed plant of Prunus serrulata LiNDL. $f$. purpurea Mryos. (no m. ja p. Murasakizakura), with double flowers (Prunus serrulata Lind. $f$. purpurea-plena nov. $f$. nom. ja p. Yae-Murasakizakura) is worthy of mention.")

This tree was raised from the seed of 1907 . It produces yearly perfectly double flowers with more than 10 petals, while the size and colour of the blossoms are nearly the same as in the mother tree.

In the mother tree the flowers are always single, - there is no sign of doubleness, neither extra petals nor banner shaped imperfect petals have ever been observed.

The present case is interesting, as it shows a highly doubleflowered form can arise at once from the strictly single-flowered one. In September 1926

1) Mryoshi, M. Dia japanischen Bergkirschen, usw. Journ. Coll. Sci. Imp. Univ. Tokyo, XXXIV. 1. 1916, p. 158.

2) Mryoshi, M. Die japanischen Bergkirschen, usw. 1. c. p. 160; Ditto, Japanese cंherries. II. Fig. 79. 